DOI: $10.29303 /$ jrpb.v9i2.266

ISSN 2301-8119, e-ISSN 2443-1354

Tersedia online di http://jrpb.unram.ac.id/

\title{
OPTIMASI KONDISI EKSTRAKSI ULTRASONIKASI PADA VITAMIN C BUAH DELIMA (Punica granatum L.) MENGGUNAKAN RESPON PERMUKAAN
}

\author{
Optimization of Ultrasonication Extraction Conditions in Vitamin C Pomegranate (Punica
} granatum L.) using Surface Response

\section{S.Rosalinda ${ }^{1 *}$, Hilda Ayu Aulia ${ }^{1}$, Asri Widyasanti ${ }^{1}$, Efri Mardawati ${ }^{2}$}

${ }^{1}$ Laboratorium Pascapanen dan Teknologi Proses, Departemen Teknik Pertanian dan Biosistem, Fakultas teknologi Industri Pertanian Universitas Padjadjaran, J1. Raya Bandung

Sumedang Km.21, Jatinangor, Kabupaten Sumedang, Jawa Barat, Indonesia 45363

${ }^{2}$ Departemen Teknologi Industri Pertanian Fakultas Teknologi Industri Pertanian Universitas Padjadjaran, Jl. Raya Bandung Sumedang Km.21, Jatinangor, Kabupaten Sumedang, Jawa Barat Indonesia 45363

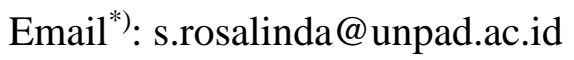

Diterima: Juli 2021

Disetujui: September 2021

\begin{abstract}
Pomegranate (Punica granatum L.) is a plant that has many benefits, including antioxidant content. The main antioxidant content in pomegranate is vitamin $C$. Vitamin $C$ as an antioxidant is needed in the immune system to maintain immunity and maintain skin elasticity. The content of vitamin C from a pomegranate can be obtained by extraction. Vitamin $C$ is not resistant to high temperatures; therefore, proper extraction technology is needed. UltrasoundAssisted Extraction (UAE) is the ultrasonication extraction chosen because it does not use high temperatures and shorter extraction times. This study aims to determine the optimum UAE conditions, including a combination of 3 variables, namely amplitude, time, and the amount of solvent that produces optimum vitamin C from pomegranate pulp extract. The UAE device used in this study is Qsonica - Q500 type (500 W, $20 \mathrm{kHz})$. The research method is an experimental laboratory using RSM (Response Surface Methodology) type CCD (Central Composite Design) with a minimum amplitude of $40 \%$ and a maximum of 50\%; a minimum time of 20 minutes and a maximum of 25 minutes. Furthermore, the minimum amount of solvent is $150 \mathrm{ml}$, and the maximum is $225 \mathrm{ml}$. The study results concluded that a large number of solvents had a significant effect, while the amplitude and length of extraction time had no significant effect. The model was significant at $P$ value $<0.05$ with optimum UAE conditions at a combination of $50 \%$ amplitude treatment, 25 minutes, and $150 \mathrm{ml}$ of solvent, resulting in the optimum value of vitamin C content of $47.79 \mathrm{mg} / 100$ grams.
\end{abstract}

Keywords: pomegranate; RSM; UAE; vitamin C 


\begin{abstract}
ABSTRAK
Buah Delima (Punica granatum L.) merupakan tanaman yang memiliki banyak manfaat, diantaranya memiliki kandungan antioksidan. Kandungan antioksidan dalam buah delima yang utama adalah vitamin $\mathrm{C}$. Vitamin $\mathrm{C}$ sebagai antioksidan dibutuhkan dalam sistem imun untuk menjaga kekebalan tubuh dan juga dapat menjaga elastisitas kulit. Kandungan vitamin $\mathrm{C}$ dari buah delima dapat diperoleh dengan cara ekstraksi. Vitamin $\mathrm{C}$ tidak tahan pada suhu yang tinggi, sehingga dibutuhkan teknologi ekstraksi yang tepat. Ultrasound Assisted Extraction (UAE) merupakan ekstraksi ultrasonikasi yang dipilih karena tidak menggunakan suhu yang tinggi dan waktu ekstraksi lebih singkat. Penelitian ini bertujuan menentukan kondisi UAE optimum yang meliputi kombinasi 3 variabel, yaitu amplitudo, waktu, dan jumlah pelarut yang menghasilkan vitamin $\mathrm{C}$ optimum dari ekstrak daging buah delima. Tipe alat UAE yang digunakan pada penelitian ini adalah tipe Qsonica - Q500 (500 W, $20 \mathrm{kHz})$. Metode penelitian adalah eksperimental laboratorium menggunakan RSM (Response Surface Methodology) tipe CCD (Central Composite Design) dengan amplitudo minimum 40\% dan maksimum 50\%; waktu minimum 20 menit dan maksimum 25 menit; dan jumlah pelarut minimum $150 \mathrm{ml}$ dan maksimum $225 \mathrm{ml}$. Hasil penelitian menyimpulkan bahwa banyaknya jumlah pelarut memberikan pengaruh yang nyata, sedangkan amplitudo dan lama waktu ekstraksi tidak berpengaruh nyata. Model signifikan pada nilai $\mathrm{P}<0,05$ dengan kondisi UAE optimum pada kombinasi perlakuan amplitudo 50\%, waktu 25 menit, dan jumlah pelarut $150 \mathrm{ml}$ yang menghasilkan nilai kadar vitamin C optimum sebesar 47,79 mg/100 gram.
\end{abstract}

Kata kunci: buah delima; RSM; UAE; vitamin C

\title{
PENDAHULUAN
}

\section{Latar Belakang}

Pencemaran lingkungan khususnya udara merupakan masalah seluruh negara dunia khususnya di Indonesia. Menurut Badan Pusat Statistik (2018), jumlah kendaraan bermotor terus meningkat setiap tahun. Peningkatan jumlah kendaraan bermotor menyebabkan meningkatnya pencemaran udara. Menurut Fakriah, et al. (2019), asap kendaraan bermotor sangat berbahaya bagi manusia karena merupakan sumber radikal bebas yang beracun bagi tubuh manusia. Kadar radikal bebas yang melampaui kemampuan tubuh menyebabkan kondisi stress oksidatif. Stress oksidatif yang menjadi penyebab utama penyakit-penyakit dalam tubuh, seperti stroke, penyakit jantung, tekanan darah tinggi, dan kanker. Salah satu bahan aktif dalam mengurangi efek dari radikal bebas adalah Antioksidan.

Menurut Suranto (2011), buah delima memiliki kandungan antioksidan tiga kali lebih banyak dibandingkan teh hijau dan anggur merah. Buah delima memiliki kandungan antioksidan yang tinggi yaitu sebesar $62,7 \%$ dibandingkan dengan anggur $(26,6 \%)$, apel $(25,7 \%)$, dan pir $(13,7 \%)$. Buah delima merah mengandung lebih banyak vitamin $\mathrm{C}$ dibandingkan dengan buah delima putih (Karadeniz, et al., 2005). Kandungan antioksidan dalam buah delima yang utama adalah asam askorbat atau biasa disebut dengan vitamin $\mathrm{C}$ dan golongan polifenol seperti flavonoid dan tanin (Suranto, 2011). Vitamin C adalah salah satu antioksidan non enzimatis yang berfungsi untuk mencegah proses oksidasi, penuaan, gangguan kardiovaskular, hingga regenerasi sel (Suksesi \& Sirat, 2012). Vitamin C pada buah delima banyak terdapat pada daging buahnya (Fatmawati, 2019).

Kandungan vitamin $\mathrm{C}$ pada daging buah delima dapat diperoleh dengan cara melakukan ekstraksi menggunakan bantuan pelarut. Menurut Leba (2017), ekstraksi menggunakan pelarut tertentu yang sesuai merupakan salah satu teknik pemisahan 
secara kimia. Stabilitas vitamin C sangat dipengaruhi oleh suhu. Kenaikan suhu akan mempercepat reaksi oksidasi, dimana semakin tinggi suhu maka semakin tinggi juga kerusakan vitamin C (Winarno, 1997). Pencegahan kerusakan vitamin C membutuhkan teknologi ekstraksi yang tepat. Teknologi ekstraksi yang digunakan pada penelitian ini adalah ekstraksi ultrasonik. Ekstraksi UAE dengan berbantu gelombang ultrasonik mengalami fenomena kavitasi. Proses kavitasi adalah proses pembentukan, pengembangan dan pemecahan gelembung pada pelarut. Kavitasi menyebabkan membran sel tanaman rusak dan pecah. Rusak dan pecahnya membran sel tanaman menghasilkan ekstrak yang larut dalam pelarut (Wardiyati, 2004). Ekstraksi UAE memiliki penggunaan waktu yang singkat, temperatur yang rendah dan jumlah pelarut yang sedikit (Chemat, et al., 2011). Ekstraksi UAE merupakan ekstraksi pada bahan yang sensitif terhadap perubahan suhu. Ekstraksi UAE dipengaruhi oleh beberapa faktor, diantaranya adalah besar amplitudo, rasio antara padatan dan jumlah pelarut. dan lama waktu ekstraksi (Sholihah, et al., 2017). Berdasarkan faktor-faktor tersebut perlu dilakukan optimasi kondisi UAE yang meliputi besar amplitudo, lama waktu, dan rasio antara padatan dan jumlah pelarut yang menghasilkan ekstrak daging buah delima dengan vitamin C. Salah satu cara optimasi yang dikenal dalam perancangan desain adalah menggunakan metode RSM.

RSM adalah kumpulan teknik matematis dan statistik yang digunakan untuk pemodelan dan analisis masalah pada respon yang dipengaruhi oleh beberapa variabel dan bertujuan untuk mengoptimasi respon tersebut (Oramahi, 2008). RSM tidak saja digunakan untuk mengetahui pengaruh variabel terhadap respon, tetapi juga mendapatkan model matematis hubungan antara variabel dengan respon, serta mendapatkan prediksi kondisi proses yang menghasilkan respon terbaik (Nurmiah et $a l .$, 2013). RSM mampu mengidentifikasi titik di luar jangkauan percobaan yang merupakan model orde 1 dan mencari kondisi optimum suatu respon yang dipengaruhi oleh variabel yang komplek yang merupakan model orde 2 (Oramahi, 2008). Sehingga dengan model ini diharapkan akan diperoleh kondisi ekstraksi optimum dengan kandungan vitamin $\mathrm{C}$.

Berdasarkan studi literatur penentuan amplitudo, waktu, rasio pelarut terhadap bahan dan jenis pelarut pada penelitian yang dilakukan oleh Zivkovic, et al. (2018), ekstrak kulit delima terbaik didapatkan pada perlakuan dengan rasio bahan terhadap pelarut 1:44 (b:v); waktu ekstraksi selama 25 menit, dengan menggunakan pelarut etanol menghasilkan total kandungan fenolik, kandungan asam elagik kandungan punikalin. Waktu yang digunakan pada penelitian oleh Zivkovic, et al. (2018) dan Rosalinda, et al. (2019) akan digunakan sebagai acuan batas maksimum 25 menit dan batas minimum 20 menit. Besar amplitudo maksimum yang digunakan adalah sebesar $50 \%$ dan batas minimum yang digunakan sebesar 40\%. Ekstrak buah delima yang dihasilkan kemudian dilakukan pengujian kuantitatif kadar vitamin $\mathrm{C}$ dengan metode iodimetri (Sudarmadji, et al., 2010). Selain itu, dilakukan juga pengujian mutu terhadap rendemen parsial dan rendemen total, $\mathrm{pH}$ warna yang dihasilkan, bobot jenis ekstrak sebagai penggambaran tingkat kemurnian ekstrak (SNI 06-2385-2006 Minyak Nilam, 2006), serta kadar sisa pelarut pada ekstrak (Guenther, 1987).

\section{Tujuan}

Berdasarkan uraian latar belakang tersebut, tujuan penelitian adalah menentukan kondisi UAE optimum yang meliputi kombinasi 3 variabel, yaitu amplitudo, waktu, dan rasio antara padatan dan jumlah pelarut pada produksi vitamin $\mathrm{C}$ daging buah delima menggunakan RSM. 


\section{METODE PENELITIAN}

\section{Alat dan Bahan}

Bahan baku adalah buah delima merah (Punica granatum Linn) matang. Kematangan ditandai dengan warna merah yang merata. Buah delima matang menurut Pomegranate Council adalah buah delima dengan berat satuan sebesar 250 - 450 gram, dengan kulit tidak berkerut dan tidak memiliki bercak hitam. Buah delima diperoleh dari supermarket. Adapun bahan lain yang digunakan adalah pelarut etanol $96 \%$ food grade, akuades, amilum, dan larutan iodium sebagai bahan analisis.

Alat yang digunakan diantaranya adalah beaker glass (pyrex), biuret (pyrex 50 $\mathrm{ml}$ ), cawan, corong kaca (Herma), desikator, erlenmeyer (Herma), gelas ukur (Herma), kertas $\mathrm{pH}$, kertas saring (Whatmann 42), oven (Memmert), pipet (Herma), piknometer (Pyrex $1 \mathrm{ml}$ ), Rotary Vacuum Evaporator (Heidolph p/n 562 - 01300-00), termometer inframerah (GM300), timbangan analitik (Adventure-pro, ketelitian 0,0001 g), timbangan teknis (Boeco r-300, ketelitian 0,01 g), dan Ultrasonic processor (Qsonica - Q500, 500 $\mathrm{W}, 20 \mathrm{kHz})$. Ultrasonic processor dengan spesifikasi power rating 500 watts; frekuensi $20 \mathrm{KHz}$, voltage $110 \mathrm{~V}, 50 / 60 \mathrm{~Hz}$ dapat dilihat dari Gambar 1.

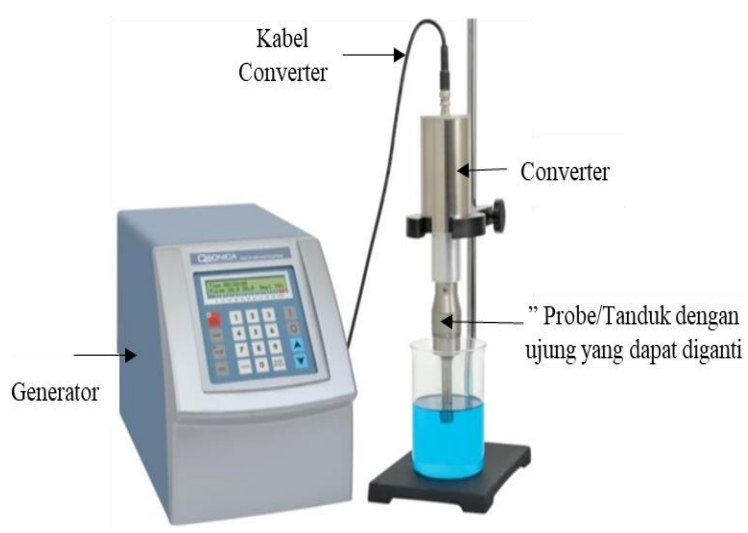

Gambar 1. Ultrasonic Processor (QsonicaQ500)

Sumber: Operation Manual Qsonica-Q500

\section{Metode}

Metode penelitian yang digunakan adalah metode eksperimen laboratorium dengan RSM tipe CCD pada design expert 11. Rancangan penelitian mengkombinasikan 3 variabel bebas yaitu amplitudo (A) dalam satuan \%, waktu (B) dalam satuan menit, dan rasio padatan dengan pelarut atau jumlah pelarut (C) dalam satuan $\mathrm{ml}$, sedangkan $\mathrm{D}$ adalah respon (D) yaitu hasil pengukuran untuk vitamin $C$ dalam satuan $\mathrm{mg} / 100 \mathrm{~g}$. Setiap variabel memiliki nilai batas maksimum $(+)$ dan batas minimum (-). Berdasarkan metode RSM tipe CCD dengan interval variabel dapat dilihat pada Tabel 1 .

Tabel 1. Nilai Interval Variabel Desain CCD

\begin{tabular}{cccccc}
$\begin{array}{c}\text { Variabel } \\
\text { Bebas }\end{array}$ & $-\boldsymbol{\alpha}$ & $\mathbf{- 1}$ & $\mathbf{0}$ & $\mathbf{+ 1}$ & $+\boldsymbol{\alpha}$ \\
\hline $\mathrm{A}$ & 37 & 40 & 45 & 50 & 53 \\
$\mathrm{~B}$ & 18,3 & 20 & 22,5 & 25 & 26,7 \\
$\mathrm{C}$ & 124,4 & 150 & 187,5 & 225 & 250,6 \\
\hline
\end{tabular}

Berdasarkan Tabel 1, rancangan percobaan dalam penelitian menghasilkan 20 sampel (run) yang terdiri dari 6 kali ulangan titik tengah (central point), 8 batas maksimum dan batas minimum (factorial point), dan 6 perlakuan di atas titik maksimum dan di bawah titik minimum (axial point).

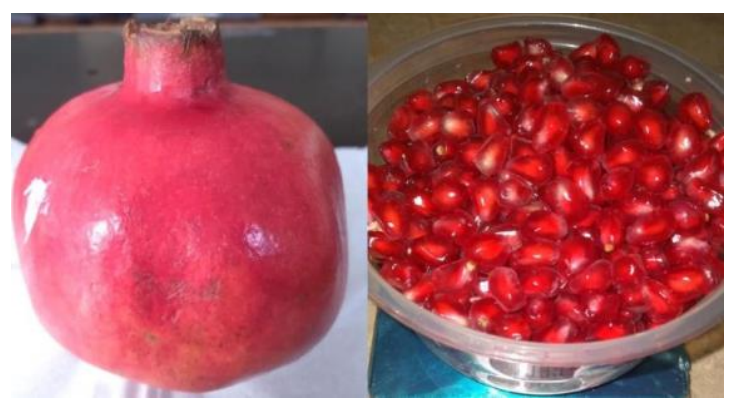

Gambar 2. Buah dan Daging Delima

Penelitian ini terdiri dari tiga tahapan. Tahap pertama persiapan bahan baku; buah delima dilakukan pencucian, selanjutnya 
dilakukan pembelahan dan pemisahan sehingga dihasilkan daging buah delima seperti Gambar 2. Daging buah delima dianalisis karakteristik bahan baku meliputi: kadar air dan kadar vitamin C.

Tahap kedua penelitian utama, yaitu sebanyak 15 gram daging buah delima dilakukan ekstraksi menggunakan UAE dengan pelarut etanol $96 \%$ food grade. Ekstraksi dilakukan sebanyak 20 run sesuai hasil dari input di RSM. Hasil ekstraksi yang dihasilkan lalu disaring hingga menghasilkan filtrat. Filtrat selanjutnya dipekatkan dengan evaporator. Ekstrak yang dihasilkan kemudian dianalisis kandungan vitamin $\mathrm{C}$.

Tahap ketiga, dilakukan analisis ekstrak dengan pengujian bobot jenis (SNI 06-23852006, 2006) dan pH (Mukaromah, et al, 2010) yang dilakukan pada 5 kondisi, yaitu pada perlakuan kondisi ekstraksi yang menghasilkan ekstrak dengan kadar vitamin C optimum, kadar vitamin $\mathrm{C}$ tertinggi, kadar vitamin $\mathrm{C}$ sedang, kadar vitamin $\mathrm{C}$ terendah, dan ekstrak dengan perlakuan kontrol. Tahapan penelitian secara keseluruhan dapat dilihat pada Gambar 3.

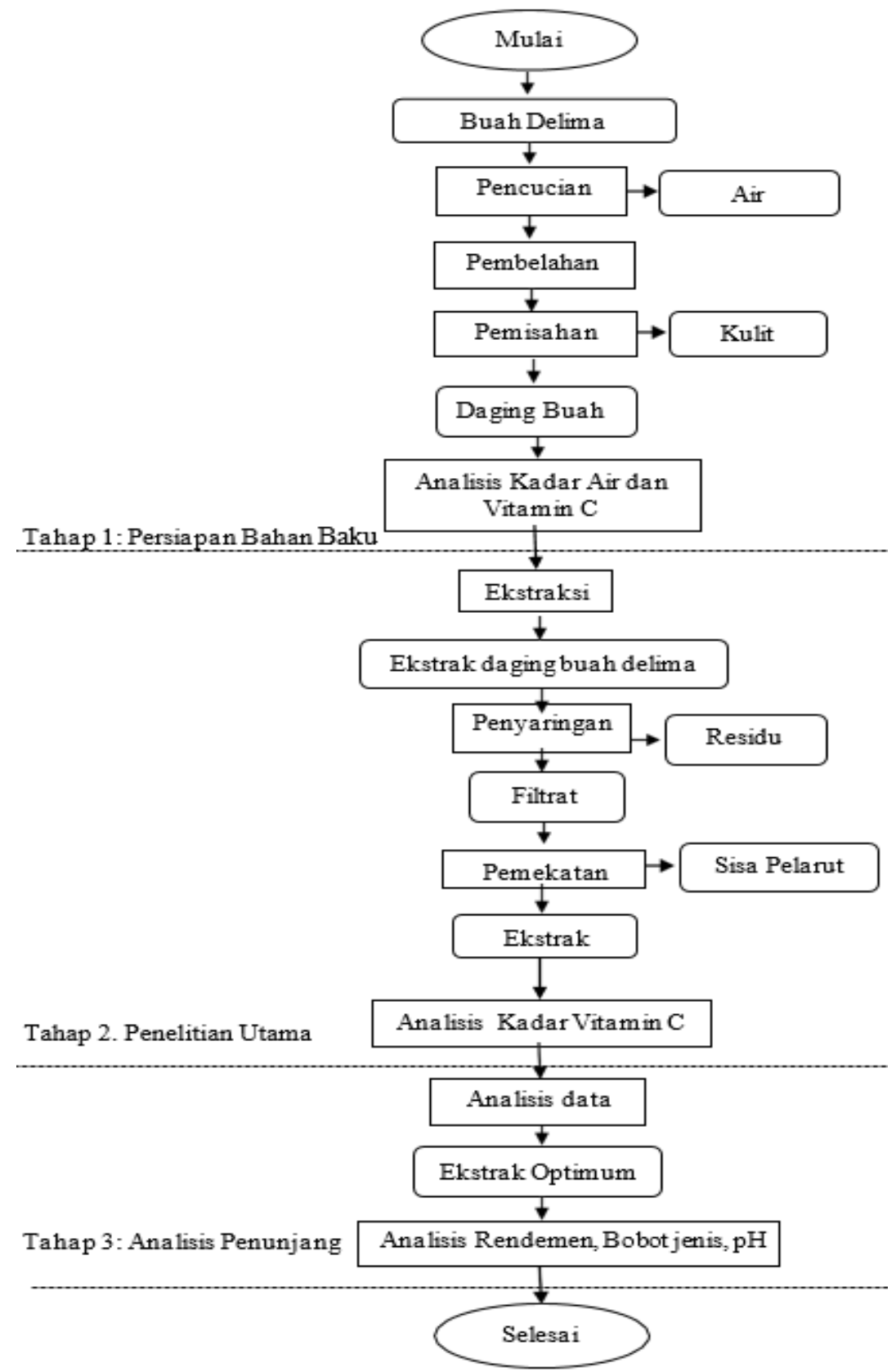

Gambar 3. Tahapan Penelitian 


\section{HASIL DAN PEMBAHASAN}

\section{Hasil Analisis Bahan Baku}

Analisis bahan baku meliputi pengujian kadar air dan pengujian kadar vitamin $\mathrm{C}$.

\section{$\underline{\text { Kadar Air }}$}

Pengujian kadar air daging buah delima dilakukan dengan cara mengeringkan daging buah delima hingga beratnya konstan. Hasil pengujian kadar air delima sebesar 82,25 $\pm 0,63 \%$. Nilai kadar air ini tidak jauh berbeda dengan penelitian yang Roswiem, et al. (2014), yang mendapatkan kadar air buah delima segar sebesar 83,11\%. Menurut Bhowmik, et al. (2013), buah delima memiliki kadar air sebesar 78,00\%. Perbedaan kadar air pada buah delima dapat dipengaruhi pada ukuran buah yang digunakan, kematangan buah, tempat tumbuh, dan kondisi pertumbuhan tanaman (Maiman \& Ahmad, 2002).

\section{$\underline{\text { Kadar Vitamin C }}$}

Pengujian vitamin $\mathrm{C}$ daging buah delima dilakukan untuk mengetahui kadar vitamin $\mathrm{C}$ pada bahan awal sehingga dapat diketahui perubahan setelah dilakukan proses ekstraksi UAE. Pengujian vitamin C pada 3 gram daging buah delima dilakukan dengan metode titrasi iodimetri. Berdasarkan pengujian vitamin $\mathrm{C}$ daging buah delima diperoleh 100,42 $\pm 3,10$ $\mathrm{mg} / 100 \mathrm{~g}$. Menurut Opara, et al. (2008), vitamin $\mathrm{C}$ buah delima berkisar antara 52,8 $\mathrm{mg} / 100 \mathrm{~g}$ sampai $72,0 \mathrm{mg} / 100 \mathrm{~g}$. Kadar vitamin $\mathrm{C}$ yang berbeda ini diduga karena kadar vitamin $\mathrm{C}$ pada suatu tanaman termasuk buah dipengaruhi oleh varietas buah, jenis tanah pada saat penanaman, suhu lingkungan, tempat tumbuh, pemakaian jenis pupuk, proses fotosintesis, polutan, paparan matahari, kondisi panen, dan tingkat kematangan (Winarno, 1984; Rahman, et al., 2015).

\section{Ekstraksi Ultrasonikasi}

Semakin lama waktu ekstraksi yang dilakukan maka suhu semakin meningkat. Suhu ekstraksi dipengaruhi oleh besarnya amplitudo yang digunakan. Proses ekstraksi ultrasonik dilakukan menggunakan energi gelombang, memiliki frekuensi sebesar 20 kHz. Gelombang ultrasonik dipancarkan melalui probe ultrasound processor yang kemudian mengenai campuran bahan pelarut etanol $96 \%$ pada daging buah delima. Setiap proses akan mengalami kenaikan suhu yang berbeda-beda, tergantung kombinasi perlakuan antara besar amplitudo, lama waktu ekstraksi, dan jumlah pelarut yang digunakan. Kenaikan suhu pada perlakuan dapat dilihat pada Gambar 4.

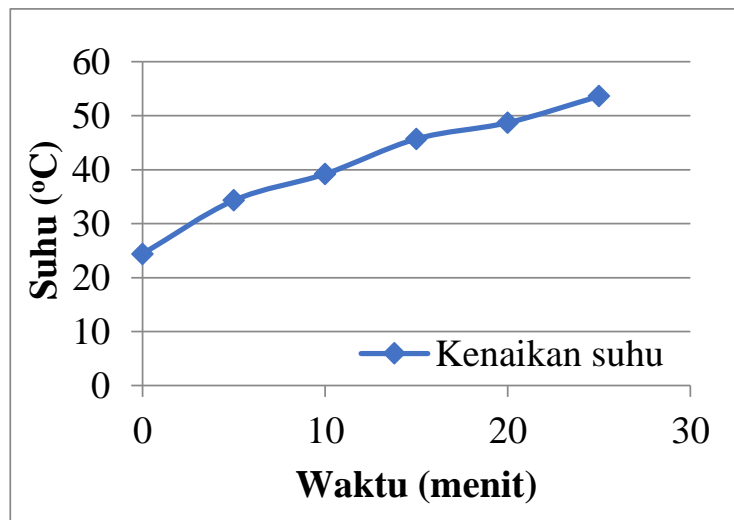

Gambar 4. Kenaikan Suhu Ekstraksi

Penerapan ultrasonik ke dalam cairan menyebabkan efek kavitasi. Efek kavitasi menyebabkan terbentuk dan pecahnya gelembung secara terus menerus. Gelombang ultrasonik bekerja dengan memindahkan energi secara mekanik. Energi gelombang merambat dengan vibrasi atau osilasi, dari satu massa ke massa berikutnya. Vibrasi ini mengakibatkan adanya gesekan antar partikel massa, yang kemudian menghasilkan panas. Semakin rapat partikel (dalam konteks ini semakin tinggi konsentrasi pelarut), jarak antar massa semakin pendek, besarnya osilasi semakin kecil, maka dengan energi eksitasi yang sama, laju perambatan semakin tinggi. (Majid, et al., 2015). 


\section{Optimasi Kondisi Ekstraksi UAE}

Variabel bebas (A, B dan C) merupakan hasil dari RSM dan D adalah respon yang merupakan hasil pengukuran vitamin C dapat dilihat pada Tabel 2. Berdasarkan Tabel 2, dapat dilihat bahwa kadar vitamin $\mathrm{C}$ yang dihasilkan berkisar antara 19,05 mg/100 gram pada run 16 yaitu dengan kombinasi amplitudo ekstraksi $45 \%$, waktu ekstraksi 22,5 menit, dan jumlah pelarut 250,6 $\mathrm{mL}$, hingga $87,21 \mathrm{mg} / 100$ gram pada run 11 yaitu dengan kombinasi amplitudo ekstraksi $45 \%$, waktu ekstraksi
22,5 menit, dan jumlah pelarut $124,4 \mathrm{~mL}$. Kadar vitamin $\mathrm{C}$ yang dihasilkan memiliki perbedaan jika dibandingkan dengan kadar vitamin $\mathrm{C}$ daging buah delima segar, yaitu sebesar 100,42 mg/100 gram. Kadar vitamin $\mathrm{C}$ dapat dipengaruhi oleh perlakuan proses pemanasan, proses oksidasi, proses pengolahan bahan dan lama penyimpanan (Andarwulan, et al., 1992). Selain itu, vitamin $\mathrm{C}$ akan mudah rusak oleh kontak dengan logam (Setyawati, et al., 2017).

Tabel 2. Variabel Bebas (A, B dan C) dan Respon (D)

\begin{tabular}{ccccc}
\hline Run & A & B & C & D \\
\hline 1 & 45 & 18,3 & 187,5 & 24,93 \\
2 & 40 & 20 & 150 & 46,92 \\
3 & 40 & 25 & 225 & 28,58 \\
4 & 50 & 20 & 225 & 35,18 \\
5 & 45 & 22,5 & 187,5 & 29,32 \\
6 & 45 & 26,7 & 187,5 & 40,31 \\
7 & 45 & 22,5 & 187,5 & 27,85 \\
8 & 40 & 25 & 150 & 41,78 \\
9 & 50 & 25 & 150 & 35,91 \\
10 & 50 & 25 & 225 & 26,39 \\
11 & 45 & 22,5 & 124,4 & 87,21 \\
12 & 40 & 20 & 225 & 29,32 \\
13 & 45 & 22,5 & 187,5 & 28,59 \\
14 & 53 & 22,5 & 187,5 & 37,38 \\
15 & 45 & 22,5 & 187,5 & 35,18 \\
16 & 45 & 22,5 & 250,6 & 19,05 \\
17 & 50 & 20 & 150 & 40,31 \\
18 & 45 & 22,5 & 187,5 & 29,32 \\
19 & 37 & 22,5 & 187,5 & 25,65 \\
20 & 45 & 22,5 & 187,5 & 27,12 \\
\hline
\end{tabular}

\section{Analysis of Variance (ANOVA)}

Analisis keseragaman (ANOVA) dilakukan berdasarkan model yang dipilih. Pemilihan model yang disarankan oleh RSM dapat dilihat pada Tabel 3. Berdasarkan Tabel 3, model quadratic tidak dipilih karena modelnya tidak signifikan, meskipun memiliki nilai $\mathrm{R}^{2}=0,4781$ lebih besar jika dibandingkan dengan model linear $\mathrm{R}^{2}=0,4047$, selain model quadratic, model 2FI juga tidak dipilih karena modelnya tidak signifikan. Model cubic juga tidak dipilih karena tidak disarankan oleh program RSM atau aliased yang berarti model cubic ini tidak akurat sesuai dengan desain pada penelitian, sehingga model cubic tidak dipertimbangkan dan tidak menunjukkan adanya persamaan matematika. Model linear dipilih karena modelnya signifikan. Signifikansi model ditunjukkan oleh nilai $\mathrm{P}$, dimana nilai $\mathrm{P}$ yang kurang dari 0,05 $(\mathrm{P}<0,05)$ menunjukkan bahwa model yang didapatkan signifikan. Hasil perhitungan ANOVA dapat dilihat pada Tabel 4. 
Tabel 3. Pemilihan model yang disarankan oleh RSM

\begin{tabular}{llllll}
\hline Source & $\begin{array}{l}\text { Sequential } \\
p \text {-value }\end{array}$ & $\begin{array}{l}\text { Lack of Fit } \\
p \text {-value }\end{array}$ & $\begin{array}{l}\text { Adjusted } \\
R^{2}\end{array}$ & $\begin{array}{l}\text { Predicted } \\
R^{2}\end{array}$ & Selection Model \\
\hline Linear & 0,0099 & 0,0019 & 0,4047 & 0,1219 & Suggested \\
2FI & 0,9635 & 0,0010 & 0,2824 & $-0,5097$ & Not significant \\
Quadratic & 0,1081 & 0,0017 & 0,4781 & $-1,0628$ & Not significant \\
Cubic & 0,0028 & 0,0522 & 0,9206 & $-2,2201$ & Aliased \\
\hline
\end{tabular}

Tabel 4. Hasil Perhitungan ANOVA

\begin{tabular}{lcccccc}
\hline Source & $\begin{array}{l}\text { Sum of } \\
\text { Square }\end{array}$ & Df & $\begin{array}{c}\text { Mean } \\
\text { Square }\end{array}$ & F value & P value & \\
\hline Model & 1888,14 & 3 & 629,38 & 5,31 & 0,0099 & Significant \\
A-Amplitudo & 7,57 & 1 & 7,57 & 0,0638 & 0,8039 & \\
B-Waktu & 3,39 & 1 & 3,39 & 0,0285 & 0,8680 & \\
C-Jumlah Pelarut & 1877,19 & 1 & 1877,19 & 15,82 & 0,0011 & \\
Residual & 1898,16 & 16 & 118,63 & & & \\
Lack of Fit & 1856,62 & 11 & 168,78 & 20,32 & 0,0019 & Significant \\
Pure Error & 41,54 & 5 & 8,31 & & & \\
Cor Total & 3786,30 & 19 & & & & \\
$\mathrm{R}^{2}$ & 0,4987 & & & & & \\
Adjusted $\mathrm{R}^{2}$ & 0,4047 & & & & & \\
Predicted $\mathrm{R}^{2}$ & 0,1219 & & & & & \\
Adeq Precision & 8,0983 & & & & & \\
\hline
\end{tabular}

Pada Tabel 4 model linear memiliki nilai $\mathrm{P}<0,05$ yaitu sebesar 0,0099 , artinya signifikan jika nilainya kecil dari $0,05(\alpha=$ 5\%). Pengaruh kondisi operasi ekstraksi daging buah delima dengan kadar vitamin C menunjukkan model adalah linear. Variabel bebas yang paling berpengaruh terhadap respon adalah jumlah pelarut dengan nilai $\mathrm{P}$ yang kecil dari 0,05 , sedangkan amplitudo tidak memiliki pengaruh terhadap respon karena modelnya tidak signifikan dengan nilai $\mathrm{P}>0,05$. Nilai lack of fit yang signifikan karena memiliki nilai $\mathrm{P}<0,05$, dimana nilai lack of fit yang signifikan menunjukkan terdapat simpangan pada data. Nilai $\mathrm{R}^{2}$ belum mendekati 1 , sedangkan model dengan data yang baik ditunjukkan dengan nilai $\mathrm{R}^{2}$ yang mendekati 1 . Selisih antara $\mathrm{R}^{2}$ adjusted dengan $\mathrm{R}^{2}$ predicted $>0,2$ yaitu sebesar 0,2828, dimana nilai selisih yang lebih dari 0,2 menunjukkan terdapat masalah dengan model atau data yang digunakan. Masalah yang menyebabkan terdapatnya simpangan pada model karena beberapa variabel bebas yang tidak signifikan sehingga kemampuan variabelvariabel bebas tersebut sangat terbatas dalam menjelaskan respon yang menyebabkan $\mathrm{R}^{2}$ memiliki nilai yang kecil.

Permasalahan pada model diduga terjadi karena pemilihan nilai rentang batas maksimum dan batas minimum variabel bebas memiliki rentang yang pendek. Contoh amplitudo dan waktu memiliki rentang yang pendek sehingga tidak memberikan pengaruh signifikan terhadap kadar vitamin $\mathrm{C}$ yang dihasilkan. Meskipun demikian, penelitian ini menunjukkan nilai rasio adequate precision yang baik yaitu sebesar 8,0983 atau lebih dari 4 (adeq prediction > 4), sehingga model pada penelitian ini dapat digunakan untuk menavigasi ruang desain RSM. Persamaan model matematis yang diperoleh dari RSM pada optimasi kombinasi variabel bebas 
terhadap respon vitamin $\mathrm{C}$ dapat dilihat pada persamaan 1 .

$\mathrm{Y}=82,11046+0,151871 \mathrm{~A}+0,199247 \mathrm{~B}-$ $0,312575 \mathrm{C}$

Dimana:

$\mathrm{Y}=$ respon vitamin $\mathrm{C}(\mathrm{mg} / 100 \mathrm{~g})$

$\mathrm{A}=$ amplitudo $(\%)$

$\mathrm{B}=$ waktu (menit)

$\mathrm{C}=$ jumlah pelarut $(\mathrm{ml})$

Persamaan tersebut dapat digunakan untuk mengetahui nilai kadar vitamin $\mathrm{C}$ yang dihasilkan apabila menggunakan nilai variabel bebas amplitudo, waktu, dan jumlah pelarut yang berbeda dari data penelitian yang dilakukan. Pada ekstraksi menggunakan UAE, semakin lama waktu yang digunakan maka rendemen yang dihasilkan akan semakin besar (Sholihah, et al., 2017). Peningkatan waktu ekstraksi berkaitan dengan kenaikan suhu proses ekstraksi, dimana menurut Wardiyati (2004), peningkatan suhu tertentu akan menyebabkan peningkatantekanan uap sehingga kavitasi akan mudah terbentuk. Efek kavitasi ini yang akan merusak sel tanaman sehingga senyawa-senyawa pada bahan akan banyak terekstrak. Gambar 5 menunjukkan vitamin $\mathrm{C}$ yang konstan dengan kenaikan persentase amplitudo dan waktu ekstraksi. Vitamin C yang kostan membuktikan bahwa sangat sedikitnya pengaruh amplitudo dan waktu ekstraksi. Pengaruh variabel amplitudo dan waktu yang tidak signifikan seperti yang ditunjukkan pada Tabel 4. Vitamin $\mathrm{C}$ akan semakin meningkat dengan berkurangnya jumlah pelarut yang digunakan yang ditunjukkan dengan nilai konstanta yang negatif pada Persamaan 1. Jumlah pelarut berkaitan dengan distribusi vitamin $\mathrm{C}$, semakin sedikit pelarut yang digunakan menyebabkan vitamin $\mathrm{C}$ tidak tersebar luas, distribusi vitamin $\mathrm{C}$ semakin sempit sehingga vitamin $\mathrm{C}$ yang dihasilkan lebih tinggi. Berbeda jika menggunakan jumlah pelarut yang besar. Vitamin $\mathrm{C}$ yang terdistribusi sangat luas sehingga kadar vitamin $\mathrm{C}$ pada ekstrak daging buah delima semakin kecil.

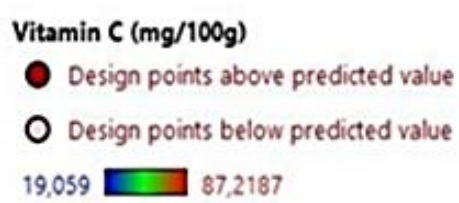

$\mathrm{X} 1=\mathrm{A}:$ Amplitudo

$\mathrm{X}_{2}=\mathrm{B}$ : Waltu

Actual Factor

C: Pelarut $=187,5$

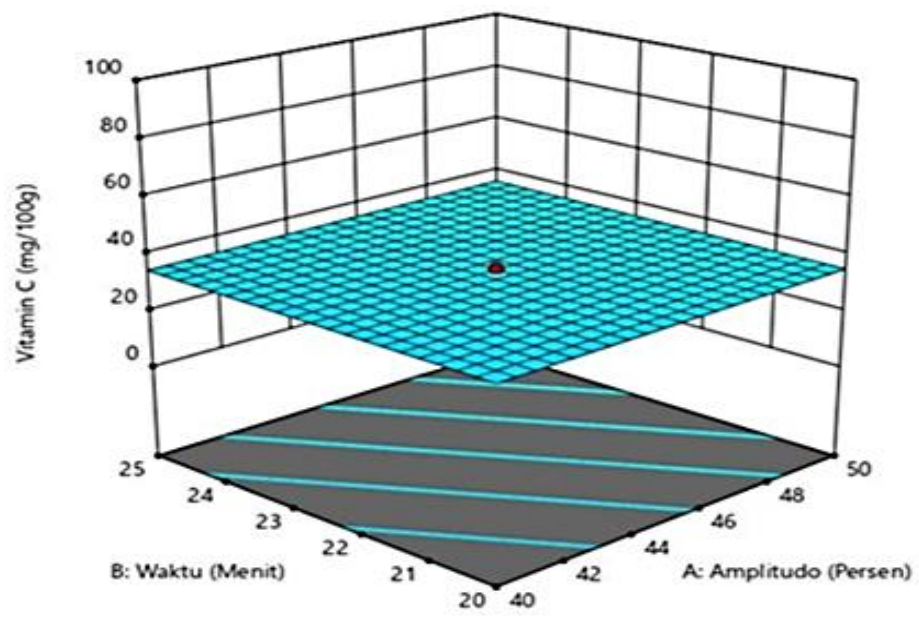

Gambar 5. Amplitudo dan Waktu terhadap Vitamin C 

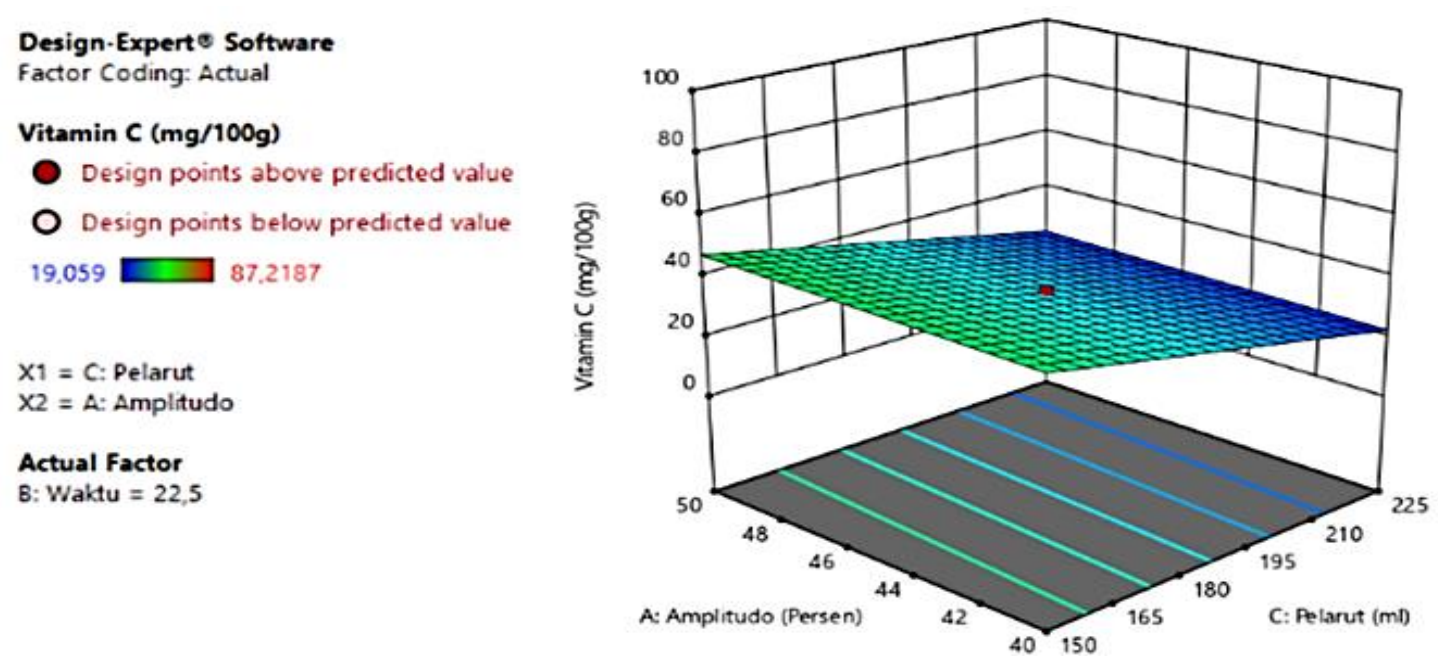

Gambar 6. Amplitudo dan Jumlah Pelarut terhadap Vitamin C

Gambar 6 menunjukkan pengaruh amplitudo dan jumlah pelarut terhadap vitamin C. Vitamin $\mathrm{C}$ akan semakin kecil dengan semakin besar jumlah pelarut yang digunakan, dapat dilihat dari warna grafik yang semakin berwarna biru. Vitamin $\mathrm{C}$ akan semakin besar sedangkan jumlah pelarut yang digunakan semakin kecil yang dapat dilihat dari warna grafik yang semakin berwarna hijau. Berdasarkan hasil penelitian ini dapat dibuktikan bahwa UAE menjadi metode ekstraksi yang sangat efektif untuk mengurangi jumlah pelarut yang dibutuhkan (Wang, et al., 2013).

\section{Hasil Optimasi dan Validasi Model}

Kombinasi perlakuan terbaik dapat diketahui dengan melakukan optimasi sehingga dapat diketahui respon yang sesuai dengan yang diharapkan. Berdasarkan proses optimasi pada penelitian ini, program Design Expert 11 memberikan 88 solusi kombinasi perlakuan. Solusi kombinasi perlakuan terbaik ditunjukkan dengan nilai target optimasi (desirability) yang tinggi, yaitu nilai desirability yang mendekati 1 . Kombinasi perlakuan pada penelitian ini yang memiliki nilai desirability tertinggi adalah pada solusi 1 , yaitu sebesar 0,422 dengan kombinasi perlakuan amplitudo sebesar 50\%, waktu ekstraksi selama 25 menit, dan jumlah pelarut sebanyak $150 \mathrm{ml}$. Kombinasi perlakuan tersebut akan menghasilkan ekstrak daging buah delima yang memiliki karakteristik sesuai dengan target optimasi sebesar $42,2 \%$, dengan prediksi vitamin C sebesar 47,7989 mg/100 gram. Hasil optimasi dan desirability tersebut dapat digambarkan dalam bentuk kontur yang dapat dilihat pada Gambar 7 . Kombinasi perlakuan dengan prediksi kadar vitamin $\mathrm{C}$ tertinggi dan nilai desirability tertinggi ditunjukkan oleh tanda panah merah pada Gambar 7. 

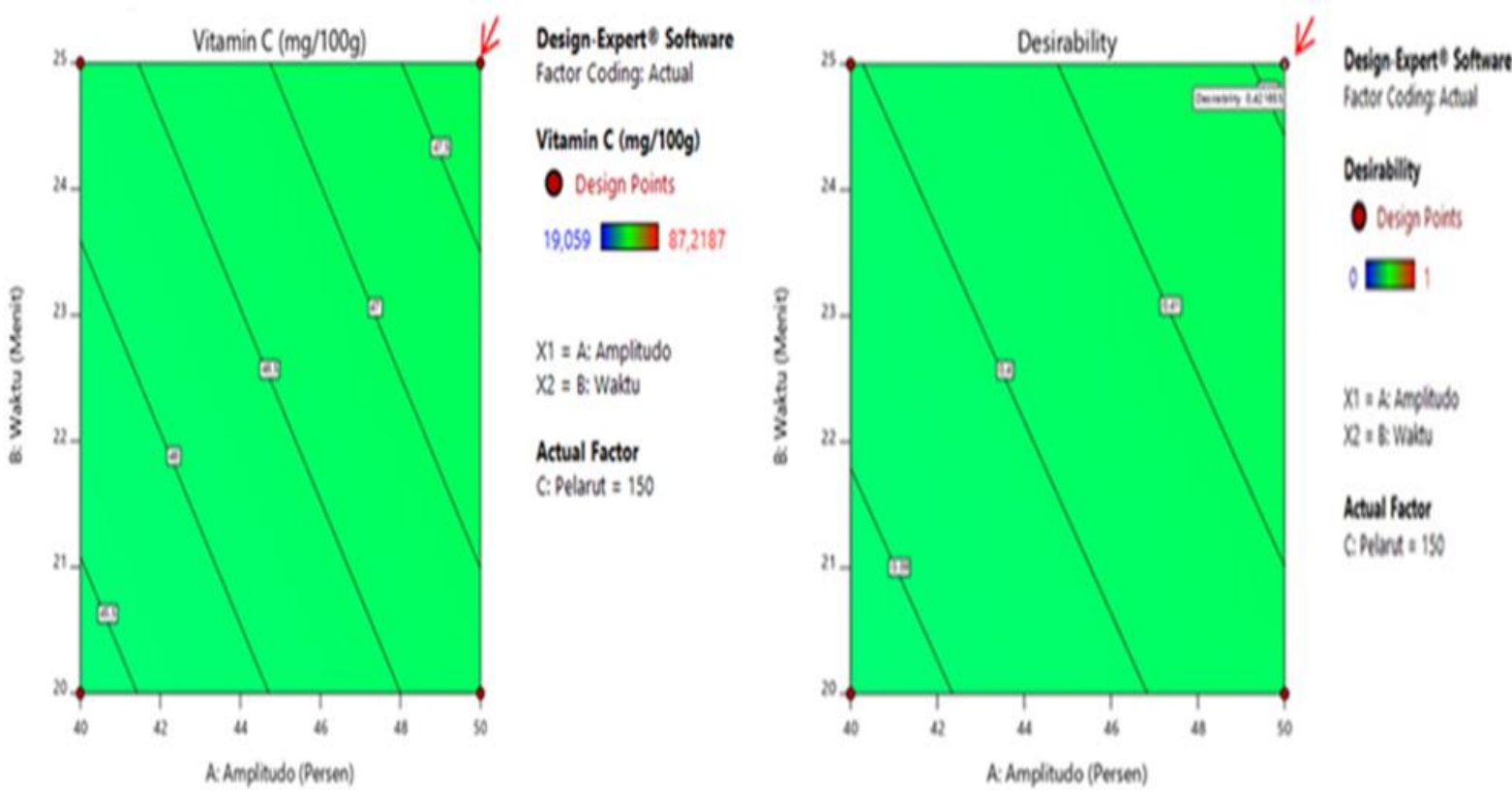

Gambar 7. Grafik Kontur Kondisi Optimum

Untuk mengetahui keakuratan model matematis, maka dilakukan validasi model. Validasi model dilakukan dengan cara membandingkan antara kadar vitamin $\mathrm{C}$ yang diprediksi oleh RSM dengan kadar vitamin $\mathrm{C}$ aktual yang diperoleh dari penelitian. Hasil validasi model dapat dilihat pada Tabel 6.

Berdasarkan Tabel 6, diketahui bahwa vitamin $\mathrm{C}$ yang diprediksi oleh RSM memiliki perbedaan dengan kadar vitamin $\mathrm{C}$ aktual yang diperoleh dari penelitian yang dilakukan. Keakuratan hasil validasi model RSM yang didapatkan masih belum mendekati $100 \%$, yaitu sebesar $75,15 \%$ yang menandakan bahwa kadar vitamin $\mathrm{C}$ hasil pengujian belum sesuai dengan nilai kadar vitamin $\mathrm{C}$ yang diprediksi RSM. Hal ini disebabkan karena lack of fit yang signifikan dan nilai $\mathrm{R}^{2}$ yang kecil yang berarti terdapat simpangan yang terjadi karena adanya masalah pada model atau data yang digunakan pada RSM sehingga perlu ditinjau kembali pemilihan nilai dan jarak batas maksimum dan batas minimum setiap variabel bebas.

\section{Hasil Analisis Ekstrak}

Pengujian karakteristik ekstrak dilakukan pada 5 kondisi, yaitu pada perlakuan kondisi ekstraksi optimum yang menghasilkan ekstrak dengan kadar vitamin C maksimum yaitu run 9, kondisi perlakuan yang menghasilkan ekstrak dengan kadar vitamin $\mathrm{C}$ tertinggi yaitu run 11, kondisi perlakuan yang menghasilkan ekstrak dengan kadar vitamin C sedang yaitu run 18, kondisi perlakuan yang menghasilkan ekstrak dengan kadar vitamin $\mathrm{C}$ terendah yaitu run 16, dan ekstrak dengan perlakuan kontrol (maserasi panas).

\section{Rendemen Total}

Rendemen total merupakan perbandingan antara massa ekstrak daging buah delima yang diperoleh dengan massa daging buah delima yang digunakan. Rendemen total setiap perlakuan tersebut dapat dilihat pada Tabel 7.

Berdasarkan Tabel 7 dapat diketahui bahwa kombinasi perlakuan yang menghasilkan rendemen total tertinggi adalah run 16 sedangkan kombinasi perlakuan yang menghasilkan rendemen total terendah adalah run 9. Dibandingkan dengan perlakuan kontrol yang hanya menghasilkan rendemen total sebesar $8,16 \%$, maka ekstraksi ultrasonik mampu menghasilkan rendemen total yang lebih banyak. Hal ini disebabkan karena ekstraksi 
ultrasonik dapat menyebabkan efek kavitasi. (Chemat \& Khan, 2011). Karena itu, ekstraksi dengan bantuan gelombang ultrasonik mampu mengekstrak senyawa- senyawa pada daging buah delima lebih banyak dibandingkan dengan perlakuan kontrol.

Tabel 6. Validasi Model

\begin{tabular}{lccccc}
\hline Run & A & B & C & D & $\begin{array}{c}\text { Hasil Validasi } \\
(\boldsymbol{\%})\end{array}$ \\
\hline Prediksi & 50 & 25 & 150 & 47,79 & 75,15 \\
Aktual & 50 & 25 & 150 & 35,91 & \\
\hline
\end{tabular}

Tabel 7. Rendemen Total

\begin{tabular}{clc}
\hline Sampel & \multicolumn{1}{c}{ Perlakuan } & Rendemen Total (\%) \\
\hline Run 9 & $\mathrm{~A}=50 \% ; \mathrm{B}=25$ menit; $\mathrm{C}=150 \mathrm{ml}$ & 13,23 \\
Run 11 & $\mathrm{~A}=45 \% ; \mathrm{B}=22,5$ menit; $\mathrm{C}=124,4 \mathrm{ml}$ & 15,17 \\
Run 16 & $\mathrm{~A}=45 \% ; \mathrm{B}=22,5$ menit; $\mathrm{C}=250,67 \mathrm{ml}$ & 28,49 \\
Run 18 & $\mathrm{~A}=45 \% ; \mathrm{B}=22,5$ menit; $\mathrm{C}=187,5 \mathrm{ml}$ & 15,49 \\
Kontrol & Maserasi Panas & 8,16 \\
\hline
\end{tabular}

\section{Bobot Jenis}

Perhitungan bobot jenis ekstrak dilakukan berdasarkan perbandingan bobot dari volume sampel dengan massa air pada suhu dan volume yang sama. Hasil pengujian bobot jenis tersaji pada Tabel 8 .

Tabel 8. Bobot Jenis

\begin{tabular}{lcc}
\hline Sampel & Perlakuan & Bobot Jenis $(\mathbf{g} / \mathbf{m l})$ \\
\hline Run 9 & $\mathrm{~A}=50 \% ; \mathrm{B}=25$ menit; $\mathrm{C}=150 \mathrm{ml}$ & 0,86 \\
Run 11 & $\mathrm{~A}=45 \% ; \mathrm{B}=22,5$ menit; $\mathrm{C}=124,4 \mathrm{ml}$ & 0,90 \\
Run 16 & $\mathrm{~A}=45 \% ; \mathrm{B}=22,5$ menit; $\mathrm{C}=250,67 \mathrm{ml}$ & 0,81 \\
Run 18 & $\mathrm{~A}=45 \% ; \mathrm{B}=22,5$ menit; $\mathrm{C}=187,5 \mathrm{ml}$ & 0,82 \\
Kontrol & Maserasi Panas & 0,85 \\
\hline
\end{tabular}

Berdasarkan hasil pengujian bobot jenis pada Tabel 8, dapat diketahui bahwa bobot jenis dipengaruhi oleh kombinasi perlakuan antara besar amplitudo, lama waktu ekstraksi dan jumlah pelarut yang digunakan. Perbedaan nilai bobot jenis ini terlihat dari run 11, 16, dan 18 yang menggunakan besar amplitudo dan waktu ekstraksi yang sama yaitu dengan amplitudo 45\% dan waktu ekstraksi 25 menit namun dengan jumlah pelarut yang berbeda. Berdasarkan data tersebut, diketahui bahwa semakin besar jumlah pelarut yang digunakan maka bobot jenisnya akan semakin kecil. Hal ini disebabkan kenaikan suhu proses ekstraksi lebih besar pada penggunaan pelarut yang lebih kecil. Menurut Wardiyati (2004), suhu yang tinggi akan menaikkan tekanan uap sehingga kavitasi akan mudah terbentuk sehingga akan lebih banyak senyawa yang terekstrak sehingga bobot jenis ekstrak akan semakin besar. Hal ini juga membuktikan bahwa UAE menjadi metode ekstraksi yang sangat 
efektif untuk mengurangi jumlah pelarut yang dibutuhkan (Wang, et al., 2013).

Hasil ekstraksi dengan bantuan gelombang ultrasonik memiliki nilai bobot jenis yang sedikit lebih besar dibandingkan dengan perlakuan kontrol. Hal ini dapat dilihat dari run 9 yang merupakan kontrol optimum menggunakan jumlah pelarut sama dengan perlakuan kontrol yaitu sebanyak $150 \mathrm{ml}$. Run 9 memiliki bobot jenis sebesar $0,86 \mathrm{~g} / \mathrm{ml}$ yaitu sedikit lebih besar dibandingkan dengan perlakuan kontrol yang memiliki kadar sisa pelarut sebesar $0,85 \mathrm{~g} / \mathrm{ml}$. Hal ini disebabkan karena proses ekstraksi daging buah delima berbantu gelombang ultrasonik sangat terbantu oleh efek kavitasi yang ditimbulkan (Chemat \& Khan, 2011). Data penelitian juga menunjukkan nilai bobot jenis setiap kombinasi perlakuan lebih kecil daripada 1 $(<1)$ yaitu lebih kecil daripada air.

Hal ini menunjukkan bahwa ekstrak daging buah delima ini memiliki bentuk fisik yang cair. Ekstrak ini juga memiliki nilai bobot jenis yang lebih tinggi dibandingkan massa jenis etanol yaitu 0,798 $\mathrm{g} / \mathrm{ml}$. Hal ini disebabkan senyawa pada daging buah delima terikat oleh etanol yang digunakan dalam proses ekstraksi, sehingga menyebabkan bobot jenis ekstrak memiliki nilai yang lebih tinggi dibandingkan massa jenis etanol.

\section{Nilai pH}

Pengujian $\mathrm{pH}$ pada penelitian ini dilakukan menggunakan kertas $\mathrm{pH}$ yang kemudian disesuaikan dengan indikator warna $\mathrm{pH}$. $\mathrm{pH}$ ekstrak daging buah delima yang diperoleh dapat dilihat pada Gambar 8 . Berdasarkan data tersebut, diketahui bahwa pH ekstrak yang diperoleh pada setiap kombinasi perlakuan memiliki $\mathrm{pH}$ yang tidak jauh berbeda, yaitu berkisar antara 56.

Nilai $\mathrm{pH}$ tersebut menunjukkan bahwa ekstrak yang diperoleh dalam kondisi asam. Nilai $\mathrm{pH}$ terendah didapatkan pada kombinasi perlakuan dengan nilai vitamin $\mathrm{C}$ tertinggi yaitu pada run 11. Vitamin C merupakan senyawa asam lemah (Atisanto et al., 2017). Sehingga semakin besar kadar vitamin $\mathrm{C}$-nya maka $\mathrm{pH}$ akan semakin rendah karena semakin asam.

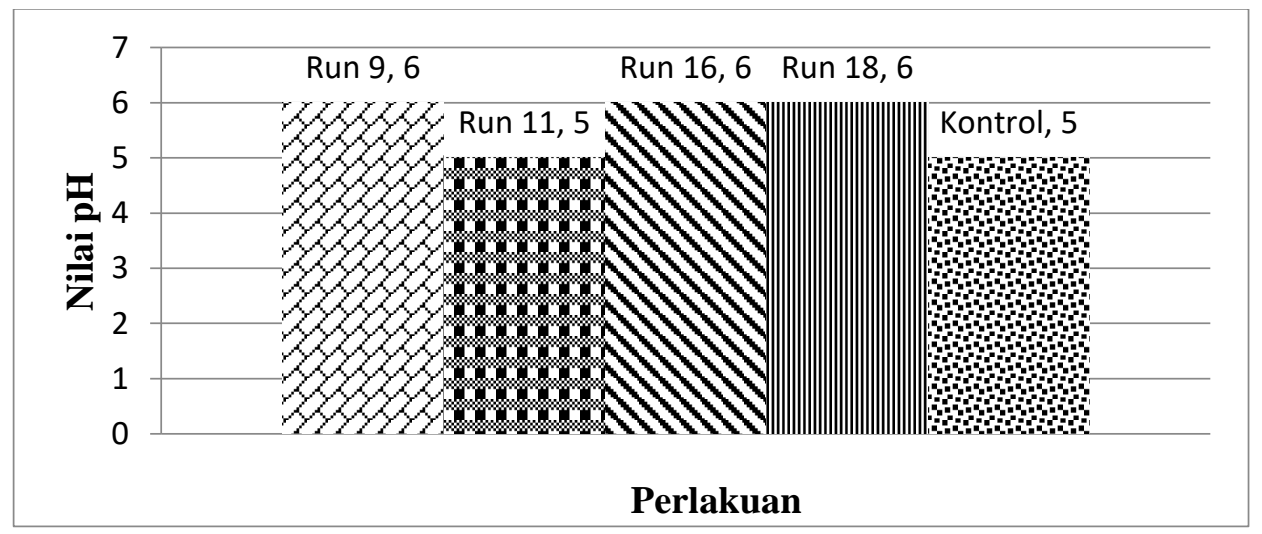

Gambar 8. Grafik Nilai pH Ekstrak Daging Buah Delima

Nilai pH pada penelitian ini dipengaruhi oleh jumlah pelarut yang digunakan. Hal ini dapat dilihat dari run 11, 16, dan 18 yang menggunakan besar amplitudo dan waktu ekstraksi yang sama yaitu dengan amplitudo $45 \%$ dan waktu ekstraksi 25 menit namun dengan jumlah pelarut yang berbeda yaitu $124,4 \mathrm{ml}$ untuk run 11, 250,6 ml untuk run 16, dan 187,5 ml untuk run 18. Berdasarkan data tersebut dan Gambar 8, diketahui bahwa nilai $\mathrm{pH}$ terendah didapat pada run 11 dengan jumlah pelarut yang kecil. Hal ini berkaitan dengan semakin sedikit jumlah pelarut yang digunakan maka semakin banyak senyawa yang terekstrak dari bahan, termasuk vitamin $\mathrm{C}$ yang merupakan senyawa asam 
lemah, sehingga nilai $\mathrm{pH}$ nya rendah karena semakin asam.

\section{KESIMPULAN DAN SARAN}

\section{Kesimpulan}

Model signifikan, model linear pada nilai $\mathrm{P}<0,05$ dengan kondisi UAE optimum pada kombinasi perlakuan amplitudo 50\%, waktu 25 menit, dan jumlah pelarut $150 \mathrm{ml}$ menghasilkan nilai kadar vitamin C maksimum sebesar 47,79 mg/100 gram berdasarkan nilai desirability tertinggi sebesar 0,422 dan dengan keakuratan validasi sebesar $75,15 \%$.

\section{Saran}

Pemilihan batas maksimum dan batas minimum variabel bebas harus lebih diperhatikan. Saran penelitian selanjutnya mengenai optimasi kondisi ekstraksi pada produksi vitamin $\mathrm{C}$ dengan metode ekstraksi berbantu gelombang ultrasonik menggunakan variabel perlakuan yang berbeda.

\section{UCAPAN TERIMA KASIH}

Penulis mengucapkan terimakasih atas pendanaan kegiatan Penelitian 2020/2021 kepada Universitas Padjadjaran dengan Skema HIU RPLK (Riset Percepatan Lektor Kepala).

\section{DAFTAR REFERENSI}

Andarwulan, N., \& Koswara, S. (1992). Kimia Vitamin. Jakarta: Rajawali.

Atisanto, S. V., Mulyani, S., \& Triani, I. G. A. L. (2017). Pengaruh jenis pelarut dan suhu pengeringan terhadap karakteristik ekstrak pada buah kelubi (Eleiodoxa conferta). Jurnal Dari Rekayasa Dan Manajemen Agroindustri, 5(3), 35-44.

Badan Pusat Statistik. (2018). Perkembangan Jumlah Kendaraan Bermotor Menurut Jenis. Diambil dari www.bps.go.id

Bhowmik, D., Gopinath, B., \& Kumar, K. (2013). Medicinal Uses of Punica granatum and Its Health Benefits. Journal of Pharmaconosy and Phytochemistry, 5, 29-36.

Chemat, F., \& Khan, M. K. (2011). Applications of ultrasound in food technology: processing, preservation and extraction. Ultrasonics sonochemistry, 18(4), 813835.Fakriah, Kurniasih, E., Adriana, \& Rusydi. (2019). Sosialisasi Bahaya Radikal Bebas dan Fungsi Antioksidan Alami Bagi Kesehatan. Jurnal Vokasi, 3(1), 1-7.

Fatmawati, S. (2019). Bioaktivitas dan Konstituen Kimia Tanaman Obat Indonesia. Yogyakarta: CV. Budi Utama.

Guenther, E. (1987). Minyak Atsiri Jilid I (Penerjemah S. Ketaren). Jakarta: Penerbit Universitas Indonesia.

Karadeniz, F., Burdurlu, H. S., Koca, N., \& Soyer, Y. (2005). Antioxidant Activity of Selected Fruits and Vegetables Grown in Turkey. Turk $J$ Agric For, 29, 297-303.

Leba, M. (2017). Buku Ajar Ekstraksi dan Real Kromatografi. Yogyakarta: CV. Budi Utama.

Maiman, A., \& Ahmad, D. S. (2002). Change in Physical and Chemical Properties During Pomegranate (Punica granatum L.) Fruit Maturation. Food Chemistry, 76, 437441.

Majid, I., Nayik, G. A., \& Nanda, V. (2015). Ultrasonication and food technology: A review. Cogent Food \& Agriculture, 1(1), 1071022. 
Mukaromah, U., Susetyorini, S. H., \& Aminah, S. (2010). Kadar vitamin C, mutu fisik, ph dan mutu organoleptik sirup rosella (Hibiscus Sabdariffa, L) berdasarkan cara ekstraksi. Jurnal Pangan dan Gizi, 1(1).

Nurmiah, S., Rizal, S., Sukarno, R. P., \& Budi, N. (2013). Aplikasi Response Surface Methodology pada Optimalisasi Kondisi Proses Pengolahan Alkali Treated Cottoni. Jurnal Kelautan dan Perikanan, VIII, 9-22.

Opara, L., Majeed, R., \& Yusra, S. (2008). Physico-Chemical Properties Vitamin C Content and Antimicrobial Properties of Pomegranate Fruit (Punica granatum L). Food Bioprocess Technol, 2, 315-321.

Oramahi, H. A. (2008). Teori dan Aplikasi Penggunaan RSM (Response Surface Methodology). Yogyakarta: Ardana Media.

Qsonica, Operation Manual Part QsonicaQ500, LLC.53 Church Hill Rd. Newtown, CT 06470 USA.

Rahman, N., Mairet, O., \& Irwan, S. (2015). Analisis Kadar Vitamin C Mangga Gadung (Mangifera sp) dan Mangga Golek (Mangifera Indica L) Berdasarkan Tingkat Kematangan dengan Menggunakan Iodimetri. Jurnal Akademi Kimia, 4(1), 33-37.

Rosalinda, S., Sarifah, N., Rudi, A., \& Nurpilihan, B. (2019). Optimalisasi Pemisahan Menggunakan Kecepatan dan Waktu Sentrifuge yang Berbeda pada Ekstraksi Pati Jagung Varietas Lokal Kabupaten Garut. Jurnal Teknotan, 13(1), 28-33.

Roswiem, A., Heryani, \& Dian, A. (2014). Aktivitas Jus Buah Delima (Punica granatum L) terhadap Peroksidasi
Lipid Darah Tikus yang diinduksi Paracetamol. Jurnal Kedokteran Yarsi, 22(2), 114-124.

Setyawati, H., \& Mustofa, A. (2017). Analisis Kadar Vitamin C Kelopak Rosella (Hibiscus sadariffa L) Muda dan Tua yang Dikoleksi dari Berbagai Ketinggian Tempat yang Berbeda. Jurnal Ilmiah Biologi (Biogenesis), 5(2), 99-103.

Sholihah, M., Ahmad, U., \& Budiastara, I. W. (2017). Aplikasi Gelombang Ultrasonik untuk Meningkatkan Rendemen Ekstraksi dan Efektivitas Antioksidan dari Kulit Manggis. Jurnal Keteknikan Pertanian, 5, 161168.

Sudarmadji, S., Haryono, B., \& Suhardi. (2010). Analisis Bahan Makanan dan Pertanian. Yogyakarta: Liberty Yogyakarta.

Suksesi \& Sirat, W. D. (2012). Antioksidan dalam Bakso Rumput Laut Merah Euchema cottoni. Jurnal Sains dan Seni Pomits, 1(1), 1-4.

Suranto, A. (2011). Terbukti Pome Tumpas Penyakit. Depok: Pustaka Bunda.

Wang, J., Yong-Ming, Z., Ya-Ting, T., Chun-Lin, Y., \& Chun-Yan, G. (2013). Ultrasound-Assisted Extraction of Total Phenolic Compounds from Inula helenium. The Scientific World Journal, 13, 1-5.

Wardiyati, S. (2004). Pemanfaatan Ultrasonik Dalam Bidang Kimia. Tangerang: Puslitbang IPTEK Bahan BATAN.

Winarno, F. G. (1984). Kimia Bahan Pangan dan Gizi. Jakarta: Gramedia Pustaka Utama.

Winarno, F. G. (1997). Kimia Pangan dan Gizi. (G. P. Utama, Ed.). Jakarta. 
Zivkovic, J., Savikin, K., Jankovic, T., Cujic, N., \& Menkovic, N. (2018). Optimization of Ultrasound-Assisted Extraction of Polyphenolic
Compounds from Pomegranate Peel using Response Surface Methodology, Separation and Purification Technology. IJRAR UGC Approved Journal, 194, 40-47. 